\title{
The transformation of rivers' temperature regime downstream of reservoirs
}

\author{
Ivan Kirvel $^{1}$, Mikhail Kukshinov ${ }^{2}$, Pavel Kirvel ${ }^{3}$ \\ ${ }^{1}$ Pomeranian University in Słupsk, Partyzantow 27, 76-200 Slupsk, Poland, e-mail: kirviel@yandex.by (corresponding author) \\ ${ }^{2}$ Scientific and practical centre of the institution «Minsk city Department of the Ministry of emergency situations \\ of the Republic of Belarus», Kozlova 26/8,220037 Minsk, Belarus, e-mail: mikuk@ yandex.ru \\ ${ }^{3}$ Belarusian State University of Informatics and Radioelectronics, P.Browki 6, 220013 Minsk, Belarus, e-mail: pavelkirviel@yandex.by
}

\begin{abstract}
The article is dedicated to the problem of the transformation of rivers' temperature conditions influenced by artificial reservoirs. A quantitative estimation of average water temperatures over ten days, and maximum and average annual water temperatures of regulated rivers downstream of reservoirs was made on the basis of the data analysis of a complete period of instrumental observations of the Republican Hydrometeorological Centre of the Republic of Belarus. It is established that the character and the parameters of the transformation of temperature conditions of the regulated rivers along with morphometric features of the reservoirs are determined by the meteorological conditions of the year and the operating conditions of the water-engineering system. The length of the cooling period effect varies from 20 days downstream of small reservoirs to 50-70 days downstream of small and average size reservoirs. The warming effect is less significant by temperature, but lasts longer and is appreciable around 200-240 days in a year. An increase in the average annual water temperature up to $0.5^{\circ} \mathrm{C}$ and a decrease in maximum temperature down to $1.1^{\circ} \mathrm{C}$ are observed in the tail-water of average size storage pools. Small size storage pools demonstrate an annual increase in annual water temperature up to $0.3^{\circ} \mathrm{C}$ and a decrease in maximum temperature down to $0.3^{\circ} \mathrm{C}$. Small size water pools show an increase both in annual water temperature up to $0.5^{\circ} \mathrm{C}$ and maximum water temperature up to $0.3^{\circ} \mathrm{C}$. Typical changes in temperature conditions of rivers are observed for a distance of 130 kilometres below the dam of average size water pools, along 70 kilometres in small water pools and along 30 kilometres in tiny ones.
\end{abstract}

Key words: temperature regime, rivers, influence of reservoirs, temperature regime transformation

\section{Introduction}

Numerous studies (Atavin et al. 2014; Avakyan 1999; Avakyan et al. 1987; Kirvel et al. 2012; Kirvel et al. 2009; Savkin 2000; Shirokov et al. 1991) show that creation of reservoirs causes major modifications of the temperature regime of regulated rivers not only upstream but also at a considerable distance downstream. The study of these changes is of practical importance as the temperature of the water, along with the mineral and chemical composition of the substances dissolved in it, determines its quality. Chemical and biological processes which happen in the river, transportation of suspended sediments by the current, etc. are connected to it. That is why even minimal shifts in one or the other side may have significant consequences for the whole ecosystem of the river. Large hydraulic engineering schemes attracted the attention of scientists, because acute ecological and economic problems existed in the location areas of these structures. By contrast, the impact of lowpressure reservoirs, which are common in Belarus, is not studied sufficiently (Kirvel et al. 2012; Kirvel et al. 2009; Shirokov et al. 1991). With increased interest in small hydropower plants and emerging climate changes advanced study of the effects of regulation of river flow is needed.

\section{Material and Methods}

The degree of influence of reservoirs on the environment is determined to the greatest extent by their size (Avakyan 1999; Avakyan et al. 1987). According to the accepted gradation there are three groups of reservoirs in Belarus which interact with the nature of the environment in different ways: tiny (volume less than 
$0.001 \mathrm{~km}^{2}$, surface area less than $3 \mathrm{~km}^{3}$ ), small (volume $0.01-0.1 \mathrm{~km}^{2}$, surface area $3-25 \mathrm{~km}^{3}$ ) and medium (volume 0.1-0.5 km², surface area $25-100 \mathrm{~km}^{3}$ ) (Shirokov et al. 1991). Based on this Vileyka, Soligorsk and Rachunsk reservoirs were taken for research. The selection of these reservoirs is specified by the presence of prolonged observations of the hydrological regime of the rivers both upstream and downstream, which allowed a qualitative statistical analysis of the changes to be carried out. Certain research was also conducted in other reservoirs of the country (Table 1).

Instrumental observation materials of the Republican Hydrometeorological Centre of the Ministry of Natural Resources and Environmental Protection of the Republic of Belarus gathered over a long period (1958-2013) and the results of the authors' own research served as the initial data.

Estimation of the transformation of the temperature regime of rivers in Belarus is conducted by the method of corresponding quantities (semigraphical method) in combination with the space difference method and regression analysis. According to the graphs of temperature connections at water posts, which were taken as analogue posts with calculation points downstream of reservoirs, qualitative evaluation of the changes is carried out (Fig. 1). According to the deviation of the data, which form a new connection after the regulation of the river, from the initial position of the connection to the regulation a conclusion is made about the change that occurred as regards the cooling or warming influence.

Statistical analysis of the significance of differences between the samples for the periods before and after the creation of the reservoir was conducted using the parametric Student's "t" test. During the analysis a 95\% confidence level was taken.
Quantitative estimation of the changes was obtained using the space difference method and regression analysis. The essence of the space difference method is that the change in the water temperature in the river at the nearest stations (posts), located in similar climatic conditions, happen at the same time and differences are persistent. This circumstance allows the effect of general climate change not connected to the creation of the reservoir to be excluded.

Hence, one can write down:

$$
T_{1}=T_{2} \pm \Delta
$$

Whence:

$$
\pm \Delta=T_{2}-T_{1},
$$

where: $T_{1}$ - difference between the average temperature of the water between the analogue post and posts located downstream of the reservoir before the regulation; $\mathrm{T}_{2}$ - difference between the average temperature of the water between the analogue post and posts located downstream of the reservoir after the regulation; $\pm \Delta$ - difference in temperature of the water caused by the reservoir.

\section{Results and Discussion}

Using the methods discussed above variations in value were estimated over a long period of on average ten days; average monthly, maximum and average annual water temperatures (for 5-10 months) of regulated rivers below the dam of reservoirs were estimated (Table 2). Dates of the highest temperature for the year in some cases at the nearby posts have no conformity due to the presence of several maximums close in value; therefore, their analysis was not performed.

\begin{tabular}{|c|c|c|c|c|c|c|c|c|}
\hline \multirow{3}{*}{ Reservoir - river basin } & \multirow{3}{*}{$\begin{array}{l}\text { Type of } \\
\text { regulation }\end{array}$} & \multicolumn{2}{|c|}{ Depth } & \multirow{2}{*}{ Length } & \multirow{2}{*}{ Area } & \multicolumn{2}{|c|}{ Volume } & \multirow{2}{*}{$\begin{array}{c}\text { Flushing } \\
\text { rate }\end{array}$} \\
\hline & & Max. & Min. & & & Full & Useful & \\
\hline & & {$[\mathrm{m}]$} & {$[\mathrm{m}]$} & {$[\mathrm{km}]$} & {$\left[\mathrm{km}^{2}\right]$} & {$\left[\mathrm{hm}^{3}\right]$} & {$\left[\mathrm{hm}^{3}\right]$} & {$\left[\mathrm{yr}^{-1}\right]$} \\
\hline Vileysky - R.Vilia & multi-year & 13.0 & 3.0 & 27.0 & 63.8 & 238.0 & 215.0 & 4.15 \\
\hline Soligorsky - R. Sluch & seasonal & 4.5 & 1.9 & 24.0 & 23.1 & 55.9 & 38.1 & 7.58 \\
\hline Petrovichsky - R. Volma & seasonal & 8.2 & 2.0 & 11.5 & 4.7 & 15.0 & 14.3 & 4.90 \\
\hline Viacha - R. Viacha & seasonal & 7.0 & 0.6 & 6.5 & 1.6 & 4.73 & 4.50 & 5.28 \\
\hline Volchkovichsky - R. Ptich & seasonal & 6.5 & 0.5 & 3.5 & 0.9 & 2.80 & 1.87 & 11.2 \\
\hline Rachunsky - R. Oshmyanka & daily & 4.7 & 0.8 & 5.5 & 1.5 & 2.29 & 1.21 & 152 \\
\hline Volma - R. Volma & daily & 3.1 & 0.4 & 2.1 & 0.5 & 0.62 & 0.53 & 134 \\
\hline
\end{tabular}

Table 1. Morphological and hydrological characteristics of the studied reservoirs 

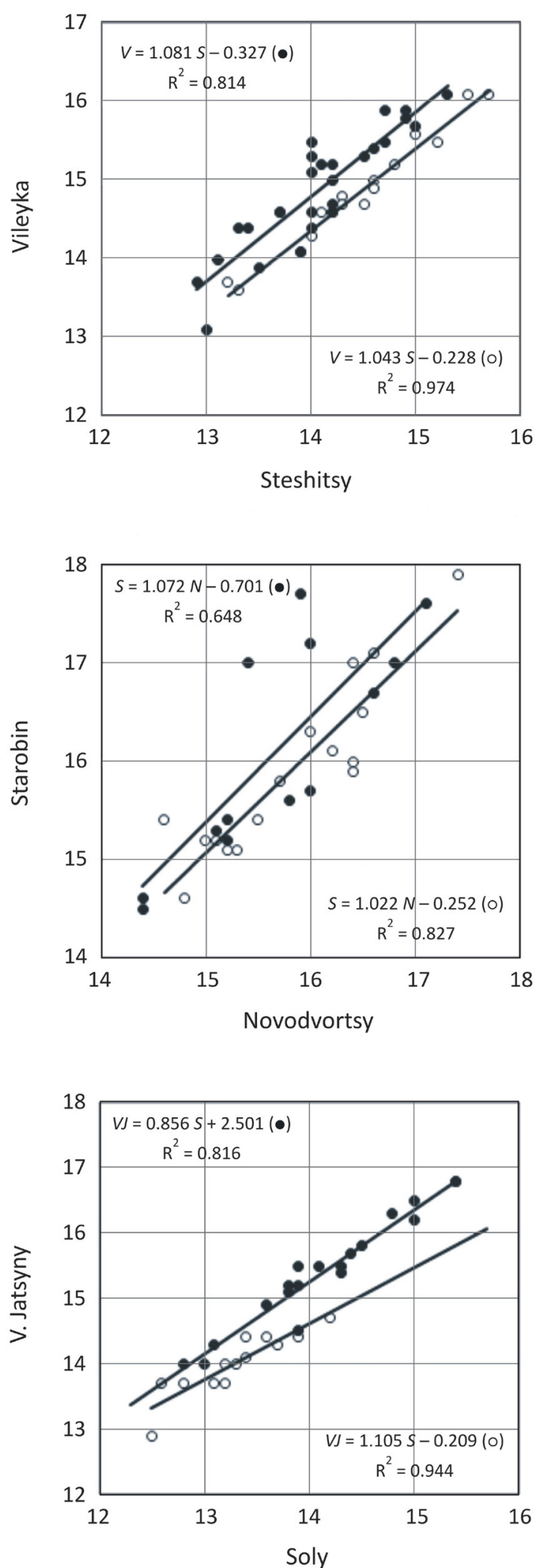

In spring from the moment of the destruction of the freeze-up, the river water flowing into the reservoir begins to heat up much faster than the water in the reservoir itself. Because of this reservoirs have a cooling effect on the temperature of the water in the river below the dam. Downstream of Vileyka reservoir the cooling effect reaches its maximum $\left(-2.7^{\circ} \mathrm{C}\right)$ in the third ten days of April, that is after about 20-30 days after the destruction of the freeze-up. Subsequently it decreases and ends in the middle of June. From this moment until the end of July, this reservoir has little effect on the temperature of the water in the river below the dam. Depending on the conditions of the year, as well as the operating mode of the hydroscheme this effect can be either mildly warming or mildly cooling, which allows this period to be considered as transitional.

In August the water in the river begins to lose heat due to climatic factors. The heat loss in the reservoir is much slower, due to the greater accumulation of heat in its water mass. Therefore, starting from August, Vileyka reservoir has a stable warming influence on the temperature regime of the river below the dam, which is highest $\left(+2.0^{\circ} \mathrm{C}\right)$ in the second half of September.

Studies have shown that the degree of cooling and warming influence of reservoirs varies greatly throughout the year, being somewhat different from the established long-term averages. For example, in late April 2013 Vileyka reservoir had a cooling effect on the temperature of the water in the river below the dam in the range of $2 \cdot 0-5.0^{\circ} \mathrm{C}$, and in the second ten days of August, a warming influence in the range of $0.7-3.3^{\circ} \mathrm{C}$.

Having considerable heat capacity, the water mass of the reservoir slightly responds to changes in weather conditions, which also helps to reduce the amplitude of diurnal fluctuations in water temperature in the river below the dam (Table 3). Autumn cooling of water ends in almost complete loss of heat, stored in the summer period. Particularly active cooling occurs in shallow areas of reservoirs with a depth of up to $0.5 \mathrm{~m}$ and according to some data it may reach $0.5^{\circ} \mathrm{C}$ per day (Shirokov et al. 1991). In the period imme-

Fig. 1. Relationship between the average annual temperature of water in the upstream and downstream posts of Vileysky Reservoir (village Steshitsy and town Vileyka), Soligorsky Reservoir (village Novodvortsy and urban settlement Starobin), Rachunsky Reservoir (village Soly and village V. Jatsyny) in the periods before (white dots) (correlation coefficients are equal 0.99/0.91/0.90, respectively) and after regulation. 
Table 2. Changes in ten-day mean water temperatures, mean annual water temperature, and maximum water temperature $\left({ }^{\circ} \mathrm{C}\right)$ downstream of Vileysky Reservoir (town Vileyka, station Zalesie, village Mikhalishki), Soligorsky Reservoir (urban settlement Starobin, urban settlement Lenin), Rachunsky Reservoir (village B.Yatsyny)

\begin{tabular}{|c|c|c|c|c|c|c|c|c|c|c|c|c|c|c|c|}
\hline \multirow{2}{*}{$\begin{array}{l}\text { Post and distance } \\
\text { to a dam }[\mathrm{km}]\end{array}$} & \multicolumn{3}{|c|}{ April } & \multicolumn{3}{|c|}{ May } & \multicolumn{3}{|c|}{ June } & \multicolumn{3}{|c|}{ July } & \multicolumn{3}{|c|}{ August } \\
\hline & 1 & 2 & 3 & 1 & 2 & 3 & 1 & 2 & 3 & 1 & 2 & 3 & 1 & 2 & 3 \\
\hline Vileyka (4.2) & -1.8 & -2.4 & -2.7 & -2.3 & -1.9 & -1.1 & -0.7 & $(-0.2)$ & $(-0.2)$ & $(-0.2)$ & $(0.2)$ & $(0.3)$ & 0.5 & 1.3 & 1.6 \\
\hline Zalesie (53.2) & -0.7 & -0.7 & -1.1 & -0.9 & -0.9 & $(-0.5)$ & $(0.0)$ & $(0.1)$ & $(0.0)$ & $(0.1)$ & $(0.0)$ & $(0.3)$ & $(0.0)$ & 0.6 & 0.9 \\
\hline Mikhalishki (134.2) & $(-0.3)$ & $(-0.4)$ & $(-0.2)$ & $(-0.3)$ & $(-0.3)$ & $(0.3)$ & $(0.5)$ & $(0.5)$ & $(0.0)$ & $(0.4)$ & $(0.4)$ & $(0.3)$ & $(0.4)$ & 0.5 & 0.6 \\
\hline Starobin (2.7) & -1.1 & -1.9 & -1.0 & -0.7 & -0.4 & $(-0.2)$ & $(-0.2)$ & $(-0.3)$ & $(0.1)$ & $(0.3)$ & $(0.3)$ & 0.5 & 0.5 & 0.7 & 0.4 \\
\hline Lenin (71.7) & $(0.3)$ & -0.6 & -0.4 & -0.5 & $(0.0)$ & $(0.3)$ & $(0.1)$ & $(0.2)$ & $(0.2)$ & $(0.4)$ & $(0.3)$ & $(0.0)$ & $(0.4)$ & $(0.3)$ & $(0.2)$ \\
\hline B.Yatsyny (27.0) & -1.1 & -0.4 & $(0.0)$ & $(0.0)$ & $(0.3)$ & $(0.5)$ & 0.6 & 0.7 & 0.8 & 0.6 & 0.6 & 1.0 & 1.0 & 0.7 & 0.7 \\
\hline \multirow{2}{*}{$\begin{array}{l}\text { Post and distance } \\
\text { to a dam }[\mathrm{km}]\end{array}$} & \multicolumn{3}{|c|}{ September } & \multicolumn{3}{|c|}{ October } & \multicolumn{3}{|c|}{ November } & \multirow{2}{*}{\multicolumn{3}{|c|}{ Mean annual }} & \multirow{2}{*}{\multicolumn{3}{|c|}{ Maximum }} \\
\hline & 1 & 2 & 3 & 1 & 2 & 3 & 1 & 2 & 3 & & & & & & \\
\hline Vileyka (4.2) & 1.9 & 2.0 & 1.9 & 1.7 & 1.2 & 1.5 & 1.0 & 0.4 & $(0.1)$ & \multicolumn{3}{|c|}{0.5} & \multicolumn{3}{|c|}{-1.1} \\
\hline Zalesie (53.2) & 0.8 & 1.1 & 0.6 & 0.6 & 0.5 & 0.6 & 0.2 & $(0.0)$ & $(0.0)$ & \multicolumn{3}{|c|}{0.2} & \multicolumn{3}{|c|}{$(0.0)$} \\
\hline Mikhalishki (134.2) & 0.6 & 0.6 & 0.4 & 0.4 & $(0.0)$ & $(0.2)$ & $(0.1)$ & $(0.0)$ & $(0.0)$ & \multicolumn{3}{|c|}{0.2} & \multicolumn{3}{|c|}{$(0.2)$} \\
\hline Starobin (2.7) & 0.4 & 0.5 & 0.6 & 0.5 & $(0.2)$ & $(0.3)$ & $(0.3)$ & $(0.1)$ & $(0.2)$ & \multicolumn{3}{|c|}{0.3} & \multicolumn{3}{|c|}{-0.3} \\
\hline Lenin (71.7) & $(0.3)$ & $(0.3)$ & $(0.3)$ & $(0.2)$ & $(0.0)$ & $(-0.2)$ & $(-0.1)$ & $(-0.2)$ & $(0.0)$ & \multicolumn{3}{|c|}{$(0.2)$} & \multicolumn{3}{|c|}{$(-0.1)$} \\
\hline B.Yatsyny (27.0) & 0.7 & 0.7 & 0.5 & $(0.0)$ & $(0.2)$ & $(-0.1)$ & $(-0.1)$ & -0.3 & -0.4 & \multicolumn{3}{|c|}{0.5} & \multicolumn{3}{|c|}{0.3} \\
\hline
\end{tabular}

Note - values which are not statistically significant at $95 \%$ confidence level are put in brackets

Table 3. Diurnal variation in water temperature $\left({ }^{\circ} \mathrm{C}\right)$ downstream and upstream of Vileysky Reservoir

\begin{tabular}{|c|c|c|c|c|}
\hline \multirow{2}{*}{ Location of the temperature measuring post } & \multicolumn{4}{|c|}{22 July 2013} \\
\hline & 08:00 & $12: 00$ & $16: 00$ & $20: 00$ \\
\hline Water temperature $3 \mathrm{~km}$ upstream from the reservoir & 19.2 & 20.6 & 22.7 & 22.4 \\
\hline Water temperature $100 \mathrm{~m}$ downstream from the reservoir & 19.4 & 19.6 & 19.9 & 19.8 \\
\hline \multirow{2}{*}{ Location of the temperature measuring post } & \multicolumn{4}{|c|}{9 August 2013} \\
\hline & 08:00 & $12: 00$ & $16: 00$ & $20: 00$ \\
\hline Water temperature $3 \mathrm{~km}$ upstream from the reservoir & 17.0 & 20.1 & 22.6 & 22.0 \\
\hline Water temperature $100 \mathrm{~m}$ downstream from the reservoir & 22.1 & 22.3 & 22.5 & 22.4 \\
\hline
\end{tabular}

diately prior to freeze-up, reservoirs have the lowest water temperature in the year. In Ivankovo Reservoir the average water temperature at the time of freezing is $0.015-0.018^{\circ} \mathrm{C}$; in Akulovskoe reservoir - about $0.1^{\circ} \mathrm{C}$; and in Khimki reservoir $-0.22^{\circ} \mathrm{C}$ (Avakyan et al. 1987). Weather conditions have a significant influence on the heat content in the reservoir just before formation of the ice cover. Thus with heavy wind mixing the heat content of the water mass is much smaller than with lower wind activity.

After the formation of the ice cover the temperature of water discharged downstream gradually increases. In winter the water temperature in Vileyka reservoir is between $0^{\circ} \mathrm{C}$ (surface) to $2.6^{\circ} \mathrm{C}$ (bottom), rarely exceeding the specified values. In fast flowing water reservoirs, to which most of the reservoirs in
Belarus belong, winter heating of water only lasts up to a certain point, after which the water starts to cool down again and reaches its second minimum at the end of winter. The greater the average depth of the reservoir is and the lower the flow it has, the higher the maximum winter water temperature is.

Thus, on average over a period of years the duration of the cooling effect of the temperature of $\mathrm{Vi}$ leyka reservoir on the River Viliya below the dam is 70 days a year, while the warming effect is 220 days. The transition period is about 70 days. The decrease in the maximum water temperature of $1.1^{\circ} \mathrm{C}$ on average and an increase in average annual temperature of $0.5^{\circ} \mathrm{C}$ are fairly typical of the regulated flow of the River Viliya.

With increasing distance from the dam of the hydroscheme the cooling and warming influence of 
the reservoir gradually fades. So, at a distance of 53.2 $\mathrm{km}$ below the dam (station Zalesie) the cooling effect of Vileyka reservoir is felt on average 50 days a year, and warming for about 90 days. The greatest difference in water temperature in natural and regulated conditions is observed in the third ten days of April $\left(-1.1^{\circ} \mathrm{C}\right)$ and in the second ten days of September $\left(+1.1^{\circ} \mathrm{C}\right)$. The decrease in the maximum temperature is not fixed, but a slight increase in its average annual values of $0.2^{\circ} \mathrm{C}$ is observed.

At a distance of $134.2 \mathrm{~km}$ below the dam (village Mikhalishki) only a warming influence of water discharged from Vileyka reservoir is found (up to $0.6^{\circ} \mathrm{C}$ ), traced from the second ten days of August to the second ten days of October, that is about 60 days a year. The cooling effect is slight; the obtained values are within $95 \%$ confidence level.

Results of the assessment of the transformation of the temperature regime of the River Sluch, after the regulation of its flow by Soligorsk reservoir, show that the maximum cooling effect of the reservoir is observed on average 10 days earlier than in Vileyka reservoir. Smaller reservoirs are more quickly warmed up and cleared of ice earlier. Shallow reservoirs with depths of up to 3 metres open earlier than deeper ones by on average 5-6 days (Shirokov et al. 1991). The geographical location of the reservoir affects the timing of the onset of the maximum cooling effect. Other conditions being equal, reservoirs in the southern part of Belarus are free of ice before the ones in the northern part.

The period of the cooling effect downstream of Soligorsk reservoir lasts on average up to the second ten days of May inclusive, which is less than in Vileyka reservoir at 20 days. Starting from August, a small (up to $+0.7^{\circ} \mathrm{C}$ ) warming influence of the reservoir is observed, which ends at the end of the first ten days of October.

The cooling effect of Soligorsk reservoir has an impact on the temperature regime of the river over a distance of more than $71.1 \mathrm{~km}$ below the dam (waterpost at the urban settlement of Lenin) and is felt from the second ten days of April to the middle of the first ten days of May. No warming influence or change in the maximum water temperature at this distance was found. It should be noted that the River Moroch, whose swamped basin is largely drained, influences the temperature of water in the River Sluch. Draining has a significant impact on the thermal regime of swamps, and consequently on the thermal regime of the feeding rivers.
Downstream of Rachunsk reservoir the duration of the spring period of the cooling effect is not long and is on average about 20 days; the maximum cooling effect $\left(-1.1^{\circ} \mathrm{C}\right)$ is registered earlier by 20 days than in Vileyka reservoir and 10 days earlier than in Soligorsk reservoir. Insignificant volumes of water mass of small reservoirs contribute to their rapid heating. Starting from June, Rachunsk reservoir has a warming influence on the temperature regime of the River Oshmyanka, which can be traced to the end of September and is characterized by small values (up to $+1.0^{\circ} \mathrm{C}$ ). An earlier onset of the warming influence than in Vileyka and Soligorsk reservoirs contributes to the fact that in contrast to these reservoirs downstream of Rachunsk reservoir there is an increase not only in the average temperature by $0.5^{\circ} \mathrm{C}$, but also in the maximum temperature by $0.3^{\circ} \mathrm{C}$.

Rachunsk reservoir manages to diffuse all the store of summer heat by September. On average over a period of years in the second ten days of November and until freeze-up this reservoir has a cooling effect on the temperature of the water in the river below the dam. In the transition to the winter period in the heat balance of the rivers feeding the reservoir, the heat which occurs in the water flow due to the transition of the kinetic energy (spent on overcoming the hydraulic resistance) into heat energy, begins to play a significant part. The temperature of water in the river below the dam is determined by the heat content of water in the reservoir, which is in the considered period, as a rule, $0^{\circ} \mathrm{C}$. This, apparently, explains the cooling effect of Rachunsk reservoir on the water temperature in the river below the dam in the period prior to the freeze-up. During the conducted research, we calculated a mathematical relationship between the values of water temperature (average ten days, average monthly, average annual and maximum) at water level measuring posts located above $(y)$ and below $(x)$ the studied reservoirs (Table 4).

These equations allow us to predict the impact of the created and planned reservoirs in Belarus on the temperature of the regulated rivers, depending on their size and the specific period of the year.

Violation of thermal conditions of regulated rivers is reflected in the timing of the onset and end of ice phenomena. Downstream of average reservoirs they begin 5-9 days later and end 30-36 days earlier than in natural conditions; below the tiny and small reservoirs the beginning of ice phenomena corresponds to the natural regime, while their end is brought forward by 18-30 days and 7-12 days respectively. 
Table 4. The dimensions of thermodynamic glades downstream of reservoirs. Temperatures are given in Celsius degrees

\begin{tabular}{|c|c|c|c|c|c|c|c|}
\hline \multirow{3}{*}{ Reservoir } & \multirow{3}{*}{$\begin{array}{c}\text { Data } \\
\text { (Air temp.) }\end{array}$} & \multicolumn{5}{|c|}{ Water temperature } & \multirow{3}{*}{$\begin{array}{l}\text { Length of the iceless } \\
\text { river downstream } \\
\text { Of the dam }\end{array}$} \\
\hline & & \multirow{2}{*}{$\begin{array}{l}\text { River } \\
\text { upstream } \\
\text { reservoir }\end{array}$} & \multicolumn{3}{|c|}{ Reservoir near the dam } & \multirow{2}{*}{$\begin{array}{c}\text { River right } \\
\text { downstream from } \\
\text { the dam }\end{array}$} & \\
\hline & & & $\begin{array}{c}\text { Surface } \\
\text { water }\end{array}$ & $\begin{array}{c}\text { Bottom } \\
\text { water }\end{array}$ & $\begin{array}{c}\text { Discharge } \\
\text { water }\end{array}$ & & \\
\hline Vileysky & $\begin{array}{c}18.02 .2006 \\
(-4.3)\end{array}$ & 0.2 & 0.2 & 2.6 & 2.1 & 2.3 & more than $40 \mathrm{~km}$ \\
\hline Soligorsky & $\begin{array}{c}20.02 .2006 \\
(-4.0)\end{array}$ & 0.2 & 0.2 & 2.2 & 1.8 & 2.0 & about $30 \mathrm{~km}$ \\
\hline Petrovichsky & $\begin{array}{c}19.02 .2006 \\
(-4.0)\end{array}$ & 0.2 & 0.2 & 2.0 & 1.7 & 1.9 & about $25 \mathrm{~km}$ \\
\hline Volchkovichsky & $\begin{array}{c}19.02 .2006 \\
(-3.7)\end{array}$ & 0.2 & 0.2 & 1.2 & 0.8 & 1.0 & about $15 \mathrm{~km}$ \\
\hline Rachunsky & $\begin{array}{c}21.02 .2006 \\
(-3.9)\end{array}$ & 0.2 & 0.2 & 0.8 & 0.5 & 0.7 & about $10 \mathrm{~km}$ \\
\hline Viacha & $\begin{array}{c}18.02 .2006 \\
(-3.0)\end{array}$ & 0.2 & 0.2 & 2.0 & 1.6 & 1.8 & about $5 \mathrm{~km}$ \\
\hline Volma & $\begin{array}{c}19.02 .2006 \\
(-3.4)\end{array}$ & 0.2 & 0.2 & 0.3 & 0.2 & 0.2 & $0.015 \mathrm{~km}$ \\
\hline
\end{tabular}

In winter, below the dam of reservoirs a natural ice-hole is formed, the size of which in the studied reservoirs varies depending on the temperature of water incoming into the downstream section, the weather conditions and treatment of discharges from the overlying hydroscheme from a few metres to more than 40 km (Table 4).

\section{Conclusion}

Thus, studies have shown that the nature and level of changes in temperature of regulated rivers, along with morphometric characteristics of artificial reservoirs are defined by meteorological conditions and the mode of operation of the hydroscheme. The duration of the cooling effect varies from 20 days downstream of tiny reservoirs, and up to 50-70 days in the lower reach of small and medium-sized reservoirs, respectively. The warming effect is less significant in temperature, but more lasting in time, i.e. about 200240 days per year. Downstream of medium-sized reservoirs an increase in average annual water temperature to $0.5^{\circ} \mathrm{C}$ and a decrease in maximum temperature up to $1.1^{\circ} \mathrm{C}$ are observed; small size reservoirs demonstrate an increase in annual water temperature up to $0.3^{\circ} \mathrm{C}$ and a decrease in maximum temperature up to $0.3^{\circ} \mathrm{C}$; tiny sized reservoirs are characterized by an increase both in annual (up to $0.5^{\circ} \mathrm{C}$ ) and maximum water temperature (up to $0.3^{\circ} \mathrm{C}$ ). Characteristic changes in the temperature conditions of rivers are observed at a distance up to 130 kilometres below the dam of average size reservoirs, around 70 kilometres in the case of small reservoirs and around 30 kilometres in the case of tiny ones.

\section{References}

Atavin A.A., Zinoviev A.T., Kudishin A.V., 2014, Ledotermicheskij rezhim nizhnego befa novosibirskogo gidrouzla (Ice thermal regime of the Lower Pool of the Novosibirsk Hydraulic Power System), Vodn. Resur. 2(41): 123 130 [in Russian, English summary].

Avakyan A.B., 1999, Issledovanie vodokhranilishh i ikh vozdejstviya na okruzhayushhuyu sredu (Study of reservoirs and their environmental impact), Vodn. Resur. 5(26): 554-567 [in Russian, English summary].

Avakyan A.B., Saltankin V.P., Sharapov V.A., 1987, Vodokhranilischa (Reservoirs), Izd. Mysl, Moscow, pp. 325 [in Russian].

Kirvel I.I., Kukshinov M.S., 2012, Vodohranilishha: za i protiv (Reservoirs: for and against), Prirod. Resur. 1: 69-82 [in Russian, English summary].

Kirvel I.I., Kukshinov M.S., 2009, Preobrazovanie termicheskogo rezhima rek v nizhnem befe vodokhranilishh (The transformation of rivers' temperature regime downstream of reservoirs), Prirod. Resur. 1: 95-101 [in Russian, English summary].

Savkin V.M., 2000, Vodokhranilishha sibiri, vodno-ekologicheskie i vodno-xozyajstvennye posledstviya ix sozdaniya (Water reservoirs of Siberia: Consequences of their creation on water ecology and water management facilities), Sibirskij Ekologicheskij Zhurnal 2: 109-121 [in Russian, English summary].

Shirokov V.M., Lopuh P.S., Grechuhina T.D., 1991, Vodohranilischa Belarusi: prirodnye osobennosti i vzaimodeystvie s okruzhayuschey sredoy [Reservoirs of Belarus: natural features and interaction with the environment], Universitetskoe Izd., Minsk, pp. 207 [in Russian]. 